\title{
Analisis Penilaian Financial Distress Menggunakan Model Altman (Z- Score) Pada Perusahaan Farmasi Yang Terdaftar di Bursa Efek Indonesia Periode 2013-2015
}

\author{
Katarina Intan Afni Patunrui ${ }^{1)}$, Sri Yati ${ }^{2)}$ \\ 1,2) STIE Malangkuçeçwara Malang \\ Email : sriyatibsp@gmail.com
}

\begin{abstract}
This study aims to observe the financial distress assessment for pharmaceutical companies listed on the Indonesia Stock Exchange using the Altman Z-Score model. The sample is selected using purposive sampling method. Ten pharmaceutical companies were selected with the criteria listed in the Indonesia Stock Exchange (BEI) and regularly published financial reports in 2013 until 2015. Secondary data was derived from www.idx.co.id site. The results indicate that the Altman Z-Score model can be implemented in detecting the possibility of financial distress in the pharmaceutical company. One from ten companies has the lowest value of the $Z$-Score and experiencing financial distress. For two years, the company is in distress zones but in the third year, the company is managed to increase the value of the company and included in the gray zones. This company must continue to strive in order to stabilize the company's financial and asset utilization to obtain maximum profit, and until it was declared as a healthy company.
\end{abstract}

Keywords: Financial Distress, Altman z-score, pharmaceutical companies

\begin{abstract}
Abstrak
Penelitian ini bertujuan untuk mengetahui penilaian financial distress terhadap perusahaan farmasi yang terdaftar di Bursa Efek Indonesia dengan menggunakan model Altman Z-Score. Sampel dipilih dengan menggunakan metode purposive sampling. Sepuluh perusahaan farmasi dipilih dengan kriteria yang terdaftar di Bursa Efek Indonesia (BEI) dan laporan keuangan yang dipublikasikan secara reguler pada tahun 2013 sampai 2015. Data sekunder berasal dari situs www.idx.co.id. Hasilnya menunjukkan bahwa model Altman Z-Score dapat diimplementasikan dalam mendeteksi kemungkinan financial distress pada perusahaan farmasi. Satu dari sepuluh perusahaan memiliki nilai terendah dari Z-Score dan mengalami tekanan keuangan. Selama dua tahun, perusahaan berada dalam zona tertekan namun di tahun ketiga, perusahaan tersebut berhasil meningkatkan nilai perusahaan dan masuk dalam zona abu-abu. Perusahaan ini harus terus berusaha dalam rangka menstabilkan pemanfaatan aset dan keuangan perusahaan untuk mendapatkan keuntungan maksimal, dan sampai dinyatakan sebagai perusahaan yang sehat.
\end{abstract}

Kata kunci: Financial Distress, Altman z-score, perusahaan farmasi 


\section{PENDAHULUAN}

Indonesia merupakan negara berkembang dengan populasi penduduk terbesar di Asia Tenggara, sekitar 255 juta jiwa dan merupakan negara terbesar keempat di dunia (BPS, 2017). Hal ini membawa Indonesia menjadi pasar yang potensial bagi para produsen. Sebagai negara berkembang salah satu yang menjadi kebutuhan pokok masyarakat Indonesia adalah kesehatan. Dunia kesehatan erat kaitannya dengan obat-obatan dan industri farmasi. Menurut Peraturan Menteri Kesehatan Republik Indonesia Nomor 1799/MENKES/PER/XII/2010, Industri farmasi adalah badan usaha yang memiliki izin dari Menteri Kesehatan untuk melakukan kegiatan pembuatan obat atau bahan obat. Setiap tahunnya kebutuhan manusia akan kesehatan semakin meningkat terutama pada negara berkembang seperti Indonesia dengan kepadatan penduduknya. Peningkatan penawaran dan permintaan obat dimasyarakat, menjadikan persaingan antar industri farmasi menguat.

Baru-baru ini pemerintah memberikan kebijakan dengan memberlakukan Sistem Jaminan Sosial Nasional (SJSN) yang dijalankan oleh Badan Penyelenggara Jaminan Sosial (BPJS) Kesehatan. Kebijakan pemerintah ini diproyeksikan meningkatkan pasar farmasi $9 \%$ pada tahun 2014 dan semakin meningkat ditahun 2015 yaitu mencapai $11,8 \%$ menjadi $\mathrm{Rp} 56$ triliun dibanding tahun sebelumnya. Industri obat-obatan dengan resep dokter di Indonesia telah mengalami penurunan, hal ini disebabkan karena semakin banyak orang beralih ke obat generik di bawah skema Jaminan Kesehatan Nasional (JKN). Sekalipun permintaan dan penawaran obatobatan semakin meningkat 2 tahun belakangan, namun peningkatan pasar ini tidak diikuti dengan naiknya pendapatan bagi perusahaan farmasi, hal ini dikarenakan produk obat-obatan yang di produksi merupakan obat dengan harga relatif terjangkau.

Peningkatan persaingan serta perubahan kondisi pasar membuat produsen harus dengan cermat mengatasi dan mengambil keputusan dalam hal-hal yang menyangkut perusahaan. Pengaruh kinerja perusahaan dapat diukur dari hasil analisis laporan keuangan. Laporan keuangan yang diterbitkan oleh perusahaan merupakan salah satu sumber informasi tentang posisi keuangan perusahaan, kinerja serta perubahan posisi keuangan sangat berguna untuk mendukung pengambilan keputusan yang tepat. Karena laporan keuangan merupakan ringkasan dari transaksi dan aktivitas perusahaan dalam satu periode yaitu satu tahun buku. Analisis laporan keuangan yang memberikan gambaran kinerja perusahaan dapat digunakan untuk memproyeksikan aspek keuangan perusahaan dimasa yang akan datang untuk menghindari perusahaan dari kebangkrutan serta dapat menjadi penentu kebijakan dan pertimbangan bagi manajer, investor dan pemilik perusahaan.

Financial distress secara umum adalah kondisi di mana perusahaan mengalami kesulitan keuangan dan terancam bangkrut. Kebangkrutan secara umum didefinisikan sebagai keadaan di mana perusahaan mengalami kegagalan menjalankan operasional perusahaan sehingga tidak dapat menghasilkan laba dan membayar kreditur mereka. Menurut Ferbianasari (2012) financial distress adalah masalah likuiditas yang sangat parah yang tidak bisa dipecahkan tanpa perubahan ukuran dari operasi atau struktur perusahaan. Informasi financial distress ini dapat dijadikan sebagai peringatan dini atas kebangkrutan sehingga manajemen dapat melakukan tindakan secara cepat untuk mencegah masalah sebelum terjadinya kebangkrutan. Analisis Z-Score sendiri merupakan sebuah alat prediksi kebangkrutan yang dibuat oleh Dr. Edward I. Altman pada tahun 1968. 
Metode ini menggunakan rasio-rasio tertentu dalam rangka memprediksi risiko kebangkrutan sebuah perusahaan(Nugroho dan Mawardi, 2012). Variabel yang terdapat dalam formula Z-Score adalah Net Working Capital to Total Assets, Retained Earnings to Total Assets, Earning Before Interest and Taxes to Total Assets, Market Value of Equity to Book Value of Debt dan Sales to Total Asset. Analisis Z-Score digunakan untuk mengukur atau memprediksi kebangkrutan dengan tingkat ketepatan dan keakuratan yang relatif dapat dipercaya.

Oleh karena itu penelitian ini bertujuan untuk mengetahui hasil penilaian financial distress pada perusahaan farmasi yang tercatat di Bursa Efek Indonesia dengan menggunakan model Altman Z-Score yang dapat digunakan untuk mencegah masalah sebelum terjadinya kebangkrutan.

\section{LANDASAN TEORI}

\section{Kebangkrutan}

Pada dasarnya perusahaan pasti akan selalu berusaha untuk tetap eksis dalam jangka waktu yang panjang. Namun kondisi pasar yang terus menerus berubah terkadang membuat perusahaan kesulitan untuk beradaptasi sehingga perusahaan mengalami krisis yang berkepanjangan dan menuju ke arah bangkrut. Kebangkrutan (Bankruptcy) biasanya diartikan sebagai kegagalan perusahaan dalam menjalankan operasi perusahaan untuk menghasilkan laba (Supardi dan Mastuti, 2003). Menurut Undang-Undang No. 4 Tahun 1998, kebangkrutan adalah keadaan di mana suatu institusi dinyatakan oleh keputusan pengadilan bila debitur memiliki dua atau lebih kreditur dan tidak membayar sedikitnya satu utang yang telah jatuh tempo dan dapat ditagih.

Martin et.al (1995) mendefinisikan kebangkrutan sebagai kegagalan dalam beberapa arti, yaitu:
1. Kegagalan ekonomi (economic failure) Kegagalan dalam arti ekonomi biasanya berarti bahwa perusahaan kehilangan uang atau pendapatan perusahaan tidak menutup biayanya sendiri, ini berarti tingkat labanya lebih kecil dari biaya modal atau nilai sekarang dari arus kas perusahaan lebih kecil dari kewajiban. Kegagalan terjadi bila arus kas sebenarnya dari perusahaan tersebut jatuh di bawah arus kas yang diharapkan. Bahkan kegagalan dapat juga berarti bahwa pendapatan atas biaya historis dari investasinya lebih kecil daripada biaya modal perusahaan.

2. Kegagalan keuangan (financial failure)

Kegagalan keuangan bisa diartikan sebagai insolvensi yang membedakan antara dasar arus kas dan dasar saham. Insolvensi atas dasar arus kas ada dua bentuk:

a. Insolvensi teknis (technical insolvency). Perusahaan dapat dianggap gagal jika perusahaan, tidak dapat memenuhi kewajiban pada saat jatuh tempo. Walaupun total aktiva melebihi total utang atau terjadi bila suatu perusahaan gagal memenuhi salah satu atau lebih kondisi dalam ketentuan hutangnya seperti rasio aktiva lancar terhadap utang lancar yang telah ditetapkan atau rasio kekayaan bersih terhadap total aktiva yang disyaratkan. Insolvensi teknis juga terjadi bila arus kas tidak cukup untuk memenuhi pembayaran bunga pembayaran kembali pokok pada tangga tertentu.

b. Insolvensi dalam pengertian kebangkrutan. Dalam pengertian ini kebangkrutan didefinisikan dalam ukuran sebagai kekayaan bersih negatif dalam neraca konvensional atau nilai sekarang 
dari arus kas yang diharapkan lebih kecil dari kewajiban.

\section{Kesulitan Keuangan (Financial Distress)}

Financial distress merupakan tahap awal sebelum terjadinya kebangkrutan. Perusahaan akan mengalami financial distress jika arus kas operasi perusahaan tidak mampu mencukupi pemenuhan kewajiban jangka pendek seperti pembayaran bunga kredit yang telah jatuh tempo. Semakin besar kewajiban yang dimiliki perusahaan, akan menyebabkan semakin besarnya risiko terjadinya financial distress (Nasution, 2015). Financial distress juga dapat didefinisikan suatu kondisi keuangan perusahaan yang mengalami kesulitan likuiditas yang sangat parah sehingga perusahaan tidak mampu menjalankan operasi dengan baik. Altman (1968) mendefinisikan financial distress dengan mempergunakan angka-angka di dalam laporan keuangan dan merepresentasikannya dalam suatu angka, yaitu Z-Score yang dapat menjadi acuan untuk menentukan apakah suatu perusahaan berpotensi untuk bangkrut atau tidak. Altman juga mengolongkan financial distress kedalam empat istilah umum, yaitu:

\section{Economic Failure}

Economic Failure terjadi ketika pendapatan perusahaan tidak dapat menutup total biaya termasuk biaya modal. Usaha yang mengalami hal tersebut dapat meneruskan operasinya sepanjang kreditur berkeinginan untuk menyediakan tambahan modal dan pemilik dapat menerima tingkat pengembalian (return) di bawah tingkat bunga pasar.

2. Business Failure

Business Failure seringkali digunakan untuk menggambarkan berbagai macam kondisi bisnis yang tidak memuaskan. Business Failure mengacu pada sebuah perusahaan berhenti beroperasi karena ketidakmampuannya untuk menghasilkan keuntungan atau mendatangkan penghasilan yang cukup untuk menutupi pengeluaran. Sebuah bisnis yang menguntungkan dapat gagal jika tidak menghasilkan arus kas yang cukup untuk memenuhi pengeluaran.

3. Insolvency

Insolvency dapat dibedakan dalam 2 kategori yaitu: (a) Technical insolvency, merupakan kondisi di mana perusahaan tidak mampu memenuhi kewajibannya yang jatuh tempo sebagai akibat dari ketidakcukupan arus kas, dan (b) Insolvency in Bankruptcy Sense, merupakan kondisi di mana total kewajiban lebih besar dari nilai pasar total aset perusahaan sehingga memiliki ekuitas yang negatif.

4. Legal Bankruptcy

Legal Bankruptcy merupakan sebuah bentuk formal kebangkrutan dan telah disahkan secara hukum.

\section{Analisis Laporan Keuangan}

Laporan Keuangan perusahaan yang disajikan merupakan bentuk pertanggung jawaban dari masing-masing manajemen pada perusahaan dan kepada pihak-pihak yang berkepentingan pada perusahaan. Laporan keuangan bertujuan untuk memberikan informasi dan gambaran mengenai posisi keuangan dan kinerja perusahaan yang dapat dijadikan pedoman dalam mengambil keputusan bisnis. Menurut PSAK No.1 (IAI, 2012: p. 3), laporan keuangan bertujuan untuk:

1. Menyediakan informasi yang menyangkut posisi keuangan, kinerja, serta perubahan posisi keuangan suatu perusahaan yang bermanfaat bagi sejumlah besar pemakai dalam pengambilan keputusan.

2. Laporan keuangan tidak menyediakan semua informasi yang mungkin dibutuhkan pemakai dalam mengambil keputusan ekonomi karena secara umum 
menggambarkan pengaruh keuangan dan kejadian masa lalu, dan tidak diwajibkan untuk menyediakan informasi non-keuangan.

3. Laporan keuangan juga menunjukan apa yang telah dilakukan manajemen (stewardship), atau pertanggung jawaban manajemen atas sumber daya yang dipercayakan kepadanya.

Menurut Kieso (2008) tujuan pelaporan keuangan adalah untuk menyediakan informasi yang berguna bagi keputusan investasi dan kredit, informasi yang berguna dalam penilaian arus kas masa depan, dan informasi mengenai sumber daya perusahaan, klaim terhadap sumber daya tersebut. Dapat dijelaskan bahwa laporan keuangan digunakan sebagai bahan penilaian dan pengambilan keputusan investasi serta memberikan informasi tentang sumber daya yang dimiliki perusahaan.

Laporan keuangan yang memang memberikan informasi yang dibutuhkan bagi beberapa pihak serta dapat dijadikan pertimbangan dalam pengambilaan keputusan dimasa yang akan datang namun seperti penjelasan yang ada dalam PSAK diatas bahwa laporan keuangan tidak menyediakan semua informasi yang dibutuhkan pemakai oleh sebab itu diperlukan analisis untuk dapat menafsirkan laporan keuangan sehingga dapat memberikan informasi yang berguna bagi pihak yang berkepentingan dengan perkembangan kinerja perusahaan.

Menurut Jumingan (2011) analisis rasio keuangan yaitu, Angka yang menunjukkan hubungan antara suatu unsur dengan unsur lainnya dalam laporan keuangan. Hubungan antara unsur-unsur laporan keuangan tersebut dinyatakan dalam bentuk matematis yang sederhana. Secara individual rasio itu kecil artinya kecuali jika dibandingkan dengan suatu rasio standar yang layak dijadikan dasar pembanding. Apabila tidak ada standar yang dipakai sebagai dasar pembanding dari penafsiran rasio-rasio suatu perusahaan, penganalis tidak dapat menyimpulkan apakah rasiorasio itu menunjukkan kondisi yang menguntungkan atau tidak menguntungkan.

\section{Z-Score}

Model Altman z-score merupakan indikator untuk mengukur potensi kebangkrutan suatu perusahaan. Sejumlah studi telah dilakukan untuk mengetahui kegunaan analisis rasio keuangan dalam memprediksi kegagalan atau kebangkrutan suatu perusahaan. Salah satu studi tentang prediksi ini adalah multiple discriminant analysis (MDA) yang biasa disebut metode Z-Score model Altman. Dasar pemikiran Altman menggunakan analisa diskriminan bermula dari keterbatasan analisa rasio yaitu metodologinya pada dasarnya bersifat suatu penyimpangan yang artinya setiap rasio diuji secara terpisah.

Variabel-variabel atau rasio-rasio keuangan yang digunakan dalam analisis diskriminan model Altman adalah (Endri, 2009 dalam Ferbianasari, 2012):

\section{Net Working Capital to Total Assets (WCTA)}

Rasio ini menunjukkan kemampuan perusahaan untuk menghasilkan modal kerja bersih dari keseluruhan total aktiva yang dimilikinya. Rasio ini dihitung dengan membagi modal kerja bersih dengan total aktiva. Modal kerja bersih diperoleh dengan cara aktiva lancar dikurangi dengan kewajiban lancar. Modal kerja bersih yang negatif kemungkinan besar akan menghadapi masalah dalam menutupi kewajiban jangka pendeknya karena tidak tersedianya aktiva lancar yang cukup untuk menutupi kewajiban tersebut. Sebaliknya, perusahaan dengan modal kerja bersih yang bernilai positif jarang sekali menghadapi kesulitan dalam melunasi kewajibannya. Dengan rumus rasio sebagai berikut: 


$$
\mathrm{X} 1: \mathrm{WCTA}=\frac{\text { Working Capital }}{\text { Total Assets }}
$$

\section{Retained Earnings to Total Assets(RETA)}

Rasio ini menunjukkan kemampuan perusahaan untuk menghasilkan laba ditahan dari total aktiva perusahaan. Laba ditahan merupakan laba yang tidak dibagikan kepada para pemegang saham. Dengan kata lain, laba ditahan menunjukkan berapa banyak pendapatan perusahaan yang tidak dibayarkan dalam bentuk dividen kepada para pemegang saham. Dengan demikian, laba ditahan yang dilaporkan dalam neraca bukan merupakan kas dan tidak tersedia untuk pembayaran dividen atau yang lain. Dengan rumus rasio sebagai berikut:

$$
\mathrm{X} 2: \text { RETA }=\frac{\text { Retained } \text { Earnings }}{\text { Total } \text { Assets }}
$$

\section{Earnings Before Interest and Tax to Total Assets(EBITTA)}

Rasio ini menunjukkan kemampuan perusahaan untuk menghasilkan laba dari aktiva perusahaan, sebelum pembayaran bunga dan pajak. Dengan rumus rasio sebagai berikut:

\begin{tabular}{c}
$\mathrm{X} 3:$ EBITTA $=$ \\
Earning Before Interest and Taxes \\
\hline
\end{tabular}

Total Assets

\section{Market Value of Equity to Book Value of Debt(MVEBVL)}

Rasio ini menunjukkan kemampuan perusahaan untuk memenuhi kewajibankewajiban dari nilai pasar modal sendiri (saham biasa). Nilai pasar ekuitas sendiri diperoleh dengan mengalikan jumlah lembar saham biasa yang beredar dengan harga pasar per lembar saham biasa. Nilai buku hutang diperoleh dengan menjumlahkan kewajiban lancar dengan kewajiban jangka panjang. Dengan rumus rasio sebagai berikut:

$$
\begin{gathered}
\text { X4 : MVEBVL }= \\
\frac{\text { Market Value of Equity }}{\text { Book Value of Total Debt }}
\end{gathered}
$$

\section{Sales to Total Assets}

Rasio ini menunjukkan apakah perusahaan menghasilkan volume bisnis yang cukup dibandingkan investasi dalam total aktivanya. Rasio ini mencerminkan efisiensi manajemen dalam menggunakan keseluruhan aktiva perusahaan untuk menghasilkan penjualan dan mendapatkan laba. Dengan rumus rasio sebagai berikut:

$$
\mathrm{X} 5: \mathrm{STA}=\frac{\text { Sales }}{\text { Total Assets }}
$$

Ramadhani dan Lukviarman (2009) dalam Ferbianasari (2012) menyatakan setelah melakukan penelitian terhadap variabel dan sampel yang dipilih, Altman menghasilkan model kebangkrutan yang pertama. Persamaan kebangkrutan yang ditujukan untuk memprediksi sebuah perusahaan publik manufaktur. Persamaan dari model Altman pertama yaitu :

$$
\begin{gathered}
\mathrm{Z}=1,2(\text { WCTA })+1,4(\text { RETA })+3,3 \\
(\text { EBITTA })+0,6(\text { MVEBVL })+1(\text { STA })
\end{gathered}
$$

Keterangan:

$\mathrm{Z}$ = bankruptcy index

$\mathrm{X} 1=$ working capital $/$ total asset

$\mathrm{X} 2=$ retained earnings $/$ total asset

$\mathrm{X} 3=$ earnings before interest and taxes/total asset

$\mathrm{X} 4$ = market value of equity / book value of total debt

X5 = sales $/$ total assets.

\section{Intrepretasi Nilai Z-Score}

Apabila perhitungan metode Z-Score telah dilakukan dengan serangkaian rasio-rasio keuangan yang dimasukkan dalam suatu persamaan diskriminan maka akan 
menghasilkan suatu angka atau skor tertentu. Angka ini memiliki penjelasan atau interprestasi tertentu.

Dalam model tersebut perusahaan yang mempunyai skor $\mathrm{Z}>2,99$ diklasifikasikan sebagai perusahaan sehat, sedangkan perusahaan yang mempunyai skor $\mathrm{Z}<1,81$ diklasifikasikan sebagai perusahaan potensial bangkrut. Selanjutnya skor 1,81 sampai 2,99 diklasifikasikan sebagai perusahaan pada grey area atau daerah kelabu (Muslich, 2000).

Berdasarkan uraian tinjauan pustaka maka model teori yang digunakan dalam penelitian ini, diilustrasikan dalam Gambar 1 berikut ini:

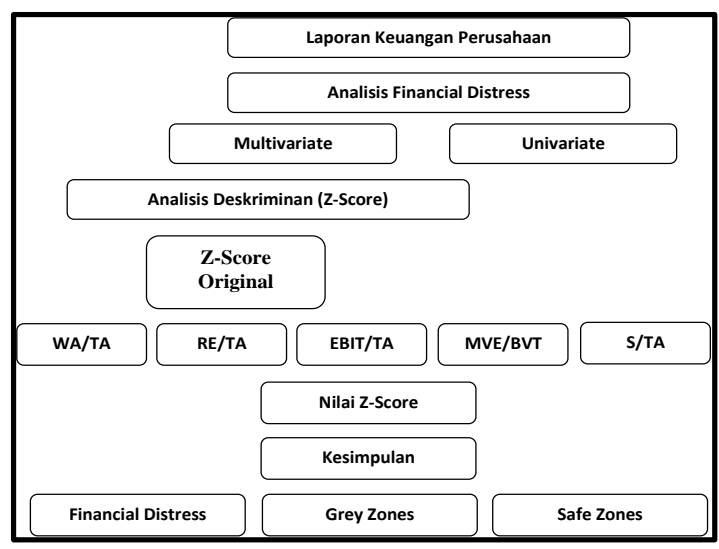

Gambar 1. Model Teori

\section{METODE}

\section{Jenis Penelitian}

Penelitian ini adalah penelitian kuantitatif dengan menggunakan analisis statistik deskriptif, yaitu penelitian yang dilakukan untuk mengetahui dan menjelaskan karakteristik variabel yang diteliti dalam suatu situasi. Tujuan penelitian deskriptif adalah memberikan kepada peneliti sebuah riwayat atau untuk menggambarkan aspekaspek yang relevan dengan fenomena perhatian dari perspektif seseorang, organisasi, orientasi industri, atau lainnya yang kemudian penelitian ini membantu peneliti untuk memberikan gagasan untuk penyelidikan dan penelitian lebih lanjut atau membuat keputusan tertentu yang sederhana (Sekaran, 2006).

\section{Populasi dan Sampel}

Populasi pada penelitian ini adalah Perusahaan Farmasi yang terdaftar di Bursa Efek Indonesia. Sedangkan sampel penelitian ditetapkan dengan menggunakan teknik purposive sampling yaitu teknik penentuan sampel dengan pertimbangan hal-hal tertentu. Arikunto (2006) menjeleskan bahwa purposive sampling adalah teknik mengambil sampel dengan tidak berdasarkan random, daerah atau strata, melainkan berdasarkan atas adanya pertimbangan yang berfokus pada tujuan tertentu. Adapun kriteria pengambilan sampel dalam penelitian ini adalah sebagai berikut:

1. Sampel penelitian adalah perusahaan farmasi yang sudah go public dan terdaftar di Bursa Efek Indonesia hingga tahun 2015

2. Perusahaan farmasi yang menerbitkan laporan keuangan lengkap berisi neraca, laporan laba rugi dan laporan arus kas pada periode yang berakhir 31 Desember tahun 2013 hingga 2015.

Table 1. Sampel Penelitian

\begin{tabular}{|c|c|l|l|}
\hline $\begin{array}{c}\text { N } \\
\text { o }\end{array}$ & $\begin{array}{c}\text { Kode } \\
\text { Saham }\end{array}$ & \multicolumn{1}{|c|}{ Nama Perusahaan } & $\begin{array}{c}\text { Tanggal } \\
\text { Pendaftaran }\end{array}$ \\
\hline 1 & DVLA & $\begin{array}{l}\text { Darya Varia Laboratoria } \\
\text { Tbk }\end{array}$ & $\begin{array}{l}11 \text { Nopember } \\
1994\end{array}$ \\
\hline 2 & INAF & Indofarma Tbk & $\begin{array}{l}17 \text { April } \\
2001\end{array}$ \\
\hline 3 & SIDO & $\begin{array}{l}\text { Industri Jamu dan Farmasi } \\
\text { Sido Muncul Tbk }\end{array}$ & $\begin{array}{l}18 \text { Desember } \\
\text { 2013 }\end{array}$ \\
\hline 4 & KLBF & Kalbe Farma Tbk & 30 Juli 1991 \\
\hline 5 & KAEF & Kimia Farma Tbk & 04 Juli 2001 \\
\hline 6 & MERK & Merck Indonesia Tbk & 23 Juli 1981 \\
\hline 7 & SCPI & $\begin{array}{l}\text { Merck Sharp Dohme } \\
\text { Pharma Tbk }\end{array}$ & 08 Juni 1990 \\
\hline 8 & PYFA & Pyridam Farma Tbk & $\begin{array}{l}\text { 16 Oktober } \\
\text { 2001 }\end{array}$ \\
\hline 9 & SQBB & $\begin{array}{l}\text { Taisho Pharmaceutical } \\
\text { Indonesia Tbk }\end{array}$ & $\begin{array}{l}\text { 29 Maret } \\
1983\end{array}$ \\
\hline 1 & TSPC & Tempo Scan Pasific Tbk & $\begin{array}{l}\text { 17 Januari } \\
1994\end{array}$ \\
\hline 0 & &
\end{tabular}

Sumber: www.idx.co.id 


\section{Metode Pengumpulan Data}

Penelitian ini menggunakan jenis data sekunder. Sumber data sekunder yang diambil berupa laporan keuangan perusahaan farmasi pada periode tahun 2013 - 2015. Data laporan keuangan tahunan perusahaan farmasi diambil dari Bursa Efek Indonesia melalui web www.idx.co.id. Study pustaka (Library Research) juga dilakukan dengan cara mempelajari serta mengkaji sumber bacaan yang berupa buku pustaka, artikel yang berkaitan tentang objek yang diteliti, jurnal penelitian, penelitian terdahulu dan sumber lainnya yang berkaitan dengan objek yang diteliti.

\section{Variabel Penelitian}

Menurut Sugiyoni (2012) variabel penelitian adalah suatu atribut atau sifat atau nilai dari orang, objek atau kegiatan yang mempunyai variansi tertentu yang ditetapkan peneliti untuk dipelajari kemudian ditarik kesimpulannya. Dalam penelitian ini penulis membagi variabel menjadi dua jenis berdasrkan hubungan antara variabel satu dengan yang lain:

\section{Variabel Independen}

Variabel Independen atau variable bebas merupakan variabel yang mempengaruhi faktor-faktor yang diukur oleh peneliti untuk menentukan hubungan antara fenomena yang diamati. Variabel bebas adalah variabel yang dapat mempengaruhi timbulnya variabel terikat atau dependent. Dalam penelitian ini yang merupakan variabel independen yaitu rasio keuangan dengan metode Altman Z-Score. Rasiorasio tersebut yaitu: WCTA(Working Capital to Total Assets), RETA(Retained Earning to Total Assets), EBITTA(Earning Before Interest and Taxes to Total Assets), MVEBL(Market Value of Equity to Book Value of Total Debt) dan STA(Sales to Total Assets).
Setelah perhitungan Z-score dengan rasiorasio keuangan yang dimasukan pada suatu persamaan diskriminan dilakukan maka akan menghasilkan skore tertentu. Angka ini memiliki penjelasan atau interpretasi tertentu. Dalam model ini, perusahaan yang memiliki score $Z>2,99$ diklasifikasikan sebagai perusahaan sehat, sedangkan perusahaan yang mempunyai score $\mathrm{Z}<1,81$ diklasifikasikan sebagai perusahaan potensial bangkrut. Selanjutnya skore 1,81 sampai 2,99 diklasifikasikan sebagai perusahaan pada grey area atau daerah kelabu (Muslich, 2000)

2. Variabel Dependen

Variabel dependen atau variabel terikat adalah faktor-faktor yang diobservasi menentukan adanya pengaruh variabel bebas yaitu faktor muncul atau tidak munculnya yang di tentukan oleh peneliti. Variabel dependen atau variabel terikat dari penelitian ini yaitu kondisi perusahaan yang sehat atau mengalami financial distress dari hasil penilaian Z-Score. Altman menyatakan bahwa jika perusahaan memiliki indeks kebangkrutan 2,99 atau lebih maka perusahaan tidak termasuk perusahaan yang dikategorikan akan mengalami kebangkrutan. Sedangkan perusahaan yang memiliki indeks kebangkrutan 1,81 atau kurang maka perusahaan masuk dalam kategori financial distress.

\section{Metode Analisis}

Penelitian ini dilakukan dengan menggunakan metode analisis laporan keuangan dengan analisis diskriminan Altman Z-score bardasarkan data laporan keuangan yang diperoleh dari website Bursa Efek Indonesia (http://www.idx.co.id) yang akan digunakan untuk mengukur kinerja keuangan perusahaan. Persamaan yang digunakan dengan model Altman diformulasikan sebagai berikut 
$\mathrm{Z}=\mathbf{1 , 2}($ WCTA $)+1,4$ (RETA) $+3,3$ (EBITTA) + 0,6 (MVEBVL) + 1 (STA)

Perhitungan pesamaan ini menggunakan lima rasio variable yaitu:

1. Modal kerja terhadap total harta (Working Capital to Total Assets)

2. Laba yang ditahan terhadap total harta (Retained Earnings to Total Assets)

3. Pendapatan sebelum pajak dan bunga terhadap total harta (Earnings Before Interest and Taxes to Total Assets)

4. Nilai buku ekuitas terhadap nilai buku dari hutang (Book Value Equity to Book Value of Total Debt)

5. Penjualan terhadap total harta (Sales to Total Assets)

Perhitungan menggunakan persamaan ini dapat dilakukan untuk menganalisis perusahaan yang sudah go public maupun perusahaan yang belum go public.

\section{HASIL PENELITIAN}

Hasil perhitungan Z-Score pada 10 perusahaan yang menjadi sampel penelitian diuraikan berikut ini.

\section{PT Darya Varia Laboratoria Tbk}

Tabel 2 menggambarkan hasil perhitungan Z-Score PT Darya Varia Laboratoria untuk tahun 2013 sampai dengan 2015. Hasil perhitungan analisis Z-Score pada tahun 2013 PT Darya Varia Laboratoria mempunyai nilai $\mathrm{Z}$ sebesar 3,45 yang termasuk dalam safe zones, pada tahun 2014 perusahaan berada dalam status grey zones ,terjadi penurunan menjadi 2,73. Penurunan yang paling dominan adalah X5 hal ini mencerminkan efisiensi manajemen dalam menggunakan keseluruhan aktiva perusahaan untuk menghasilkan penjualan dan mendapatkan laba tidak efektif.
Tabel 2. Hasil Perhitungan Z-Score PT Darya Varia Laboratoria Tahun 20132015

\begin{tabular}{|l|l|l|l|l|l|l|l|}
\hline R & & & & \multicolumn{2}{l|}{$\begin{array}{l}\text { Dari } \\
2013\end{array}$} & \multicolumn{2}{l}{$\begin{array}{l}\text { Dari } \\
2014 \\
\text { TI } \\
\text { Oe }\end{array}$} \\
ke
\end{tabular}

Penurunan nilai $\mathrm{Z}$ pada tahun 2014 juga disertai adanya peningkatan pada X2 dan $\mathrm{X} 4$ yang menunjukkan bahwa perusahaan semakin baik dalam menghasilkan laba ditahan dari total aktiva yang menggambarkan bahwa umur perusahaan sudah lama dan menujukan kemampuan perusahaan dalam memenuhi kewajibankewajiban dari nilai pasar modal sendiri. Tahun 2015 nilai $\mathrm{Z}$ kembali turun menjadi 2,56 tetapi posisi perusahaan masih dalam grey zones. Variabel yang dominan dalam penurunan ini yaitu $\mathrm{X} 4$, yang menunjukkan bahwa tidak efektifnya kemampuan perusahaan dalam memenuhi kewajibannya dari nilai pasar modal sendiri. Yang perlu 
dipertimbangkan lagi adalah penurunan variabel X1 baik pada tahun 2013 maupun 2014 mengalami penurunan yang tinggi menandakan bahwa kondisi likuiditas yang semakin buruk karena modal kerjanya menyusut secara relatif terhadap total aktivanya.

\section{PT Indofarma Tbk}

Tabel 3 menggambarkan hasil perhitungan Z-Score PT Indofarma Tbk untuk tahun 2013 sampai dengan 2015.

Tabel 3. Hasil Perhitungan Z-Score PT Indofarma Tahun 2013-2015

\begin{tabular}{|c|c|c|c|c|c|c|c|}
\hline $\begin{array}{l}\text { RA } \\
\text { TI } \\
\mathbf{O}\end{array}$ & 2013 & 2014 & 2015 & \multicolumn{2}{|c|}{$\begin{array}{l}\text { Dari } \\
2013 \\
\text { ke } \\
2014\end{array}$} & \multicolumn{2}{|c|}{$\begin{array}{l}\text { Dari } \\
2014 \\
\text { ke } \\
2015\end{array}$} \\
\hline $\mathrm{X} 1$ & 0,116 & 0,146 & 0.144 & $\pi$ & $\begin{array}{l}0, \\
03\end{array}$ & $\searrow$ & $\begin{array}{l}0, \\
00 \\
2\end{array}$ \\
\hline $\mathrm{X} 2$ & 0,128 & 0,162 & 0,135 & $\pi$ & $\begin{array}{l}0, \\
03 \\
4\end{array}$ & $\searrow$ & $\begin{array}{l}0 \\
02 \\
7\end{array}$ \\
\hline X3 & $-0,041$ & 0,006 & 0,009 & $\lambda$ & $\begin{array}{l}0, \\
04 \\
7 \\
\end{array}$ & $\lambda$ & $\begin{array}{l}0, \\
00 \\
3\end{array}$ \\
\hline $\mathrm{X} 4$ & 0,433 & 0,468 & 0,329 & $\lambda$ & $\begin{array}{l}0, \\
03 \\
5\end{array}$ & $\searrow$ & $\begin{array}{l}0, \\
13 \\
9\end{array}$ \\
\hline X5 & 0,872 & 1,105 & 1,058 & $\lambda$ & $\begin{array}{l}0, \\
23 \\
3\end{array}$ & $\searrow$ & $\begin{array}{l}0, \\
04 \\
7\end{array}$ \\
\hline $\begin{array}{l}\text { Z- } \\
\text { Sco }\end{array}$ & \multicolumn{3}{|c|}{$\begin{array}{l}\mathrm{Z}=1,2(\mathrm{X} 1)+1,4(\mathrm{X} 2)+ \\
3,3(\mathrm{X} 3)+0,6(\mathrm{X} 4)+1 \\
(\mathrm{X} 5)\end{array}$} & & & & \\
\hline & 1,32 & 1,81 & 1,65 & & & & \\
\hline $\begin{array}{l}\text { Kat } \\
\text { ego } \\
\text { ri }\end{array}$ & $\begin{array}{l}\text { Distres } \\
s \text { Zones }\end{array}$ & $\begin{array}{l}\text { Grey } \\
\text { Zone } \\
s\end{array}$ & $\begin{array}{l}\text { Distres } \\
s \text { Zones }\end{array}$ & & & & \\
\hline
\end{tabular}

Sumber: data diolah

Hasil perhitungan analisis Z-Score di atas dapat dilihat bahwa pada tahun 2013 PT Indofarma mempunyai nilai $\mathrm{Z}$ sebesar 1,32 yang artinya perusahaan berada pada kategori bangkrut atau Distress Zones. Namun pada tahun 2014 perusahaan berhasil keluar dari Distress Zones dan posisi perusahaan berada dalam Grey Zones dengan nilai $Z$ yaitu 1,81. Penyebab perusahaan dapat keluar dari grey zones adalah semua variabel $X$ mengalami peningkatan, hal ini membuktikan bahwa perusahaan berusaha secara maksimal untuk mengelola seluruh elemen keuangannya sehingga dapat berfungsi lebih baik namun perusahaan tetap masih dalam kondisi rawan. Pada tahun 2015 perusahaan kembali mengalami posisi distress dengan penurunan nilai $\mathrm{Z}$ menjadi 1,65 . Penurunan yang mendominasi adalah penurunan pada variabel X4 yang menunjukkan perusahaan tidak dengan efektif dalam memenuhi kewajibankewajibannya. Sedangkan yang mengalami peningkatan dari tahun sebelumnya adalah variabel X3 yang menujukan kemampuan perusahaan untuk menghasilkan laba dari aktiva perusahaan sebelum pembayaran bunga dan pajak.

\section{PT Industri Jamu dan Farmasi Sido Muncul Tbk}

Tabel 4 menggambarkan hasil perhitungan Z-Score PT Industri Jamu dan Farmasi Sido Muncul Tbk untuk tahun 2013 sampai dengan 2015.

Tabel 4. Hasil Perhitungan Z-Score PT Industri Jamu dan Farmasi Sido Muncul Tahun 2013-2015

\begin{tabular}{|c|c|c|c|c|c|}
\hline $\begin{array}{l}\mathbf{R} \\
\mathbf{A} \\
\mathbf{T I} \\
\mathbf{O}\end{array}$ & 2013 & 2014 & 2015 & $\begin{array}{l}\text { Dari } \\
2013 \\
\text { ke } \\
2014\end{array}$ & $\begin{array}{l}\text { Dari } \\
2014 \\
\text { ke } \\
2015\end{array}$ \\
\hline $\mathrm{X}$ & 0,69 & 0,59 & 0,54 & 0,09 & 0,0 \\
\hline 1 & 1 & 5 & 5 & 6 & 5 \\
\hline$X$ & 0,14 & 0,15 & 0,18 & 0,01 & 0,0 \\
\hline 2 & 2 & 3 & 3 & 1 & 3 \\
\hline$X$ & 0,19 & 0,19 & 0,20 & 0,00 & 0,0 \\
\hline 3 & 7 & 5 & 0 & 2 & 05 \\
\hline$X$ & 4,38 & 7,68 & 7,58 & 3,30 & 0,1 \\
\hline 4 & 8 & 9 & 4 & 1 & 05 \\
\hline$X$ & 0,80 & 0,77 & 0,79 & 0,02 & 0,0 \\
\hline 5 & 3 & 9 & 3 & 4 & 14 \\
\hline $\begin{array}{l}\text { Z- } \\
\text { Sc } \\
\text { or }\end{array}$ & \multicolumn{3}{|c|}{$\begin{array}{l}\mathrm{Z}=1,2(\mathrm{X} 1)+1,4(\mathrm{X} 2) \\
+3,3(\mathrm{X} 3)+0,6(\mathrm{X} 4)+ \\
1(\mathrm{X} 5)\end{array}$} & & \\
\hline e & 5,11 & 6,96 & 6,91 & & \\
\hline $\begin{array}{l}\text { Ka } \\
\text { te } \\
\text { go } \\
\text { ri } \\
\end{array}$ & $\begin{array}{l}\text { Safe } \\
\text { Zone } \\
\text { s }\end{array}$ & $\begin{array}{l}\text { Safe } \\
\text { Zone } \\
\text { s }\end{array}$ & $\begin{array}{l}\text { Safe } \\
\text { Zone } \\
\text { s }\end{array}$ & & \\
\hline
\end{tabular}

Sumber: data diolah 
Berdasarkan Tabel 4 menunjukkan bahwa selama tiga tahun berturut-turut perusahaan PT Sido Muncul tetap berada dalam posisi Safe Zones. Peningkatan nilai Z dari tahun 2013 kepada tahun 2014 diikuti dengan meningkatnya nilai variabel X2 dan X4 yang menunjukkan bahwa PT Sido Muncul secara efektif dapat menghasilkan laba ditahan dari total aktiva lebih baik karena perusahaan memilik umur yang telah lama berdiri sehingga dapat dengan baik mengelola laba ditahan dan menujukan kemampuan perusahaan dalam memenuhi kewajiban-kewajiban dari nilai pasar modal sendiri. Sedangkan variabel X1, X3 dan X5 mengalami penurunan pada tahun 2014. Pada tahun 2015 PT Sido Muncul mengalami penurunan nilai $\mathrm{Z}$ menjadi 6,91 namun tetap berada dalam kondisi Safe Zones. Penurunan ini disebabkan oleh variabel X1, dan X4 yang mengalami penurunan, namun penurunan yang mendominasi adalah pada $\mathrm{X} 4$ yang pada tahun sebelumnya sempat mengalami peningkatan namun pada tahun 2015 mengalami penurunan yang cukup besar, hal ini menunjukkan bahwa pada tahun 2015 perusahaan kurang efektif dalam memenuhi kewajiban-kewajibannya.

\section{PT Kalbe Farma Tbk}

Tabel 5 berikut ini menggambarkan hasil perhitungan Z-Score PT Kalbe Farma Tbk untuk tahun 2013 sampai dengan 2015

Tabel 5. Hasil Perhitungan Z-Score PT Kalbe Farma Tahun 2013-2015

\begin{tabular}{|c|c|c|c|c|c|c|c|}
\hline $\begin{array}{l}\text { RA } \\
\text { TIO }\end{array}$ & 2013 & 2014 & 2015 & \multicolumn{2}{|c|}{$\begin{array}{l}\text { Dari } \\
2013 \\
\text { ke } \\
2014\end{array}$} & \multicolumn{2}{|c|}{$\begin{array}{l}\text { Dari } \\
2014 \\
\text { ke } \\
2015\end{array}$} \\
\hline $\mathrm{X} 1$ & 0,429 & 0,461 & 0,466 & $\pi$ & $\begin{array}{l}0,0 \\
32 \\
\end{array}$ & $\lambda$ & $\begin{array}{l}0,0 \\
05 \\
\end{array}$ \\
\hline $\mathrm{X} 2$ & 0,674 & 0,715 & 0,731 & $\lambda$ & $\begin{array}{l}0,0 \\
41 \\
\end{array}$ & $\lambda$ & $\begin{array}{l}0,0 \\
16 \\
\end{array}$ \\
\hline X3 & 0,227 & 0,222 & 0,199 & $\searrow$ & $\begin{array}{l}0,0 \\
05 \\
\end{array}$ & $\searrow$ & $\begin{array}{l}0,0 \\
23 \\
\end{array}$ \\
\hline $\mathrm{X} 4$ & 0,165 & 0,175 & 0,170 & $\nearrow$ & $\begin{array}{l}0,0 \\
10 \\
\end{array}$ & $\searrow$ & $\begin{array}{l}0,0 \\
05\end{array}$ \\
\hline
\end{tabular}

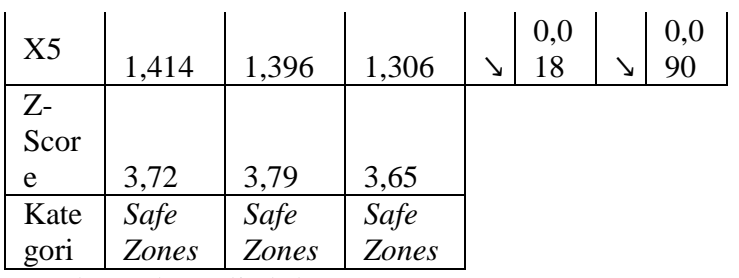

Sumber: data diolah

Sama dengan PT Sido Muncul, selama tiga tahun berturut-turut PT Kalbe Farma juga berada pada Safe Zones. Peningkatan yang dialami PT Kalbe Farma pada tahun 2014 dikarenakan adanya peningkatan variabel dan yang mendominasi peningkatan adalah variabel X2 berarti perusahaan berhasil mengelola laba sehingga laba ditahan dari total aktiva dapat terkumpul. Pada variabel X3 dan X5 mengalami penurunan yang menunjukkan kemampuan perusahaan dalam mengelola laba menurun dan mencerminkan efisiensi manajemen dalam menggunakan keseluruhan aktiva perusahaan untuk menghasilkan penjualan dan mendapatkan laba. Penurunan yang dialami PT Kalbe Farma pada tahun 2015 diikuti dengan penurunan X3, X4, X5, yang kembali mendominasi penurunan nilai ini adalah variabel X5 hal ini menunjukkan perusahaan masih belum secara efisien mampu mengelola aktiva sehingga dapat menghasilkan penjualan dan laba yang meningkat. Namun terdapat dua variabel yang meningkat pada tahun 2015 yaitu variabel X1 dan X2 yang membuktikan peningkatan kemampuan perusahaan dalam menghasilkan modal bersih dan laba dari keseluruhan aktiva.

\section{PT Kimia Farma Tbk}

Tabel 6 berikut ini menggambarkan hasil perhitungan Z-Score PT Kimia Farma Tbk untuk tahun 2013 sampai dengan 2015. PT Kimia Farma selama tahun 2013 sampai 2014 berhasil tetap berada pada posisi sehat atau safe zones dengan nilai $\mathrm{Z}$ yaitu 3,51 ditahun 2013 dan 3,14 ditahun 2014 namun pada tahun 2015 mulai menurun menjadi grey zones dengan nilai $\mathrm{Z}$ yaitu 2,62. Pada tahun 2014 penurunan terjadi karena 
hampir seluruh variabel mengalami penurunan yaitu variabel $\mathrm{X} 1, \mathrm{X} 3, \mathrm{X} 4$, dan $\mathrm{X} 5$ hanya variabel $\mathrm{X} 2$ yang mengalami peningkatan, variabel yang mendominasi penurunan adalah variabel X5 yaitu menggambarkan perusahaan yang tidak efisien dalam menggunakan keseluruhan aktiva perusahaan untuk menghasilkan penjualan dan mendapatkan laba.

Tabel 6. Hasil Perhitungan Z-Score PT Kimia Farma Tahun 2013-2015

\begin{tabular}{|c|c|c|c|c|c|c|c|}
\hline $\begin{array}{l}\text { RA } \\
\text { TIO }\end{array}$ & 2013 & 2014 & 2015 & $\begin{array}{l}\text { Da } \\
20 \\
\text { ke } \\
20 \\
\end{array}$ & $\begin{array}{l}\text { Iri } \\
13 \\
14\end{array}$ & $\begin{array}{l}\text { Da } \\
20 \\
\text { ke } \\
20 \\
\end{array}$ & $\begin{array}{l}\text { ari } \\
14 \\
15\end{array}$ \\
\hline $\mathrm{X} 1$ & 0,423 & 0,360 & 0,313 & $\searrow$ & $\begin{array}{l}0, \\
06 \\
3 \\
\end{array}$ & $\searrow$ & $\begin{array}{l}0, \\
04 \\
7\end{array}$ \\
\hline $\mathrm{X} 2$ & 0,409 & 0,413 & 0,045 & $\lambda$ & $\begin{array}{l}0, \\
00 \\
4\end{array}$ & $\searrow$ & $\begin{array}{l}0, \\
36 \\
8 \\
\end{array}$ \\
\hline $\mathrm{X} 3$ & 0,113 & 0,112 & 0,106 & $\searrow$ & $\begin{array}{l}0, \\
00 \\
1\end{array}$ & $\searrow$ & $\begin{array}{l}0, \\
00 \\
6\end{array}$ \\
\hline $\mathrm{X} 4$ & 0,545 & 0,430 & 0,545 & $\searrow$ & $\begin{array}{l}0, \\
11 \\
5 \\
\end{array}$ & $\lambda$ & $\begin{array}{l}0, \\
11 \\
5 \\
\end{array}$ \\
\hline $\mathrm{X} 5$ & 1,729 & 1,501 & 1,502 & $\searrow$ & $\begin{array}{l}0, \\
22 \\
8\end{array}$ & & $\begin{array}{l}0, \\
00 \\
1\end{array}$ \\
\hline $\begin{array}{l}\text { Z- } \\
\text { Scor } \\
\mathrm{e} \\
\end{array}$ & 3,51 & 3,14 & 2,62 & & & & \\
\hline $\begin{array}{l}\text { Kate } \\
\text { gori }\end{array}$ & $\begin{array}{l}\text { Safe } \\
\text { Zones }\end{array}$ & $\begin{array}{l}\text { Safe } \\
\text { Zones } \\
\end{array}$ & $\begin{array}{l}\text { Grey } \\
\text { Zone }\end{array}$ & & & & \\
\hline
\end{tabular}

Sumber: data diolah

Untuk tahun 2015 variabel X2 mendominasi penurunan nilai $\mathrm{Z}$ pada tahun 2015 yaitu menggambarkan kemampuan perusahaan dalam menghasilkan laba ditahan, hal ini termasuk hal yang wajar bila dilihat dari umur perusahaan berdiri yang baru melakukan go public ditahun 2001. Namun variabel X4 dan X5 meningkat pada tahun ini artinya perusahaan telah dengan baik mengelola kewajiban-kewajiban usahanya dan mengoptimalkan volume penjualannya untuk menghasilkan laba.

\section{PT Merch Sharp Dohme Tbk}

Tabel 7 berikut ini menggambarkan hasil perhitungan Z-Score PT Merch Sharp Dohme Tbk untuk tahun 2013 sampai dengan 2015.

Tabel 7. Hasil Perhitungan Z-Score PT Merck Sharp Dohme Tahun 2013-2015

\begin{tabular}{|c|c|c|c|c|c|c|c|}
\hline $\begin{array}{l}\text { RA } \\
\text { TIO }\end{array}$ & 2013 & 2014 & 2015 & \multicolumn{2}{|c|}{$\begin{array}{l}\text { Dari } \\
2013 \\
\text { ke } \\
2014\end{array}$} & \multicolumn{2}{|c|}{$\begin{array}{l}\text { Dari } \\
2014 \\
\text { ke } \\
2015\end{array}$} \\
\hline $\mathrm{X} 1$ & 0,432 & 0,471 & 0,180 & $\lambda$ & $\begin{array}{l}0, \\
03 \\
9 \\
\end{array}$ & $\searrow$ & $\begin{array}{l}0, \\
2 \\
9 \\
1\end{array}$ \\
\hline X2 & - & - & 0,022 & $\searrow$ & 0 & $\lambda$ & $\begin{array}{l}0, \\
0 \\
2 \\
2\end{array}$ \\
\hline X3 & $-0,009$ & $-0,053$ & 0,131 & $\searrow$ & $\begin{array}{l}- \\
0, \\
04 \\
4\end{array}$ & $\lambda$ & $\begin{array}{l}0, \\
1 \\
8 \\
4\end{array}$ \\
\hline $\mathrm{X} 4$ & 0,005 & 0,003 & 0,003 & $\searrow$ & $\begin{array}{l}- \\
0, \\
00 \\
2 \\
\end{array}$ & $=$ & 0 \\
\hline X5 & 0,545 & 0,73 & 1,496 & $\pi$ & $\begin{array}{l}0, \\
18 \\
5 \\
\end{array}$ & $\lambda$ & $\begin{array}{l}0, \\
7 \\
6 \\
6\end{array}$ \\
\hline $\begin{array}{l}\text { Z- } \\
\text { Sco } \\
\text { re }\end{array}$ & 1,04 & 1,12 & 2,18 & & & & \\
\hline $\begin{array}{l}\text { Kat } \\
\text { ego } \\
\text { ri }\end{array}$ & $\begin{array}{l}\text { Distres } \\
s \text { Zones }\end{array}$ & $\begin{array}{l}\text { Distres } \\
\text { s Zones }\end{array}$ & $\begin{array}{l}\text { Grey } \\
\text { Zone } \\
s\end{array}$ & & & & \\
\hline
\end{tabular}

Sumber: data diolah

PT Merch Sharp Dohme selama 2 tahun berturut-turut dalam kondisi distress, hal ini tentu sangat membahayakan perusahaan, namun demikian terjadi peningkatan pada nilai Z-Score tahun 2014. Hal ini dikarenakan nilai X1 dan X5 yang menggambarkan modal kerja bersih dari 
keseluruhan aktiva telah berjalan secara efisien dan perusahaan berhasil menghasilkan volume bisnis yang cukup dibandingkan investasi dalam total aktivanya, tetapi terjadi penurunan pada $\mathrm{X} 2$, X3 dan $\mathrm{X} 4$, penurunan tertinggi adalah pada nilai $\mathrm{X} 2$ yang menandakan bahwa pengadaan laba ditahan sebagai sumber dana pengadaan aktiva kurang baik, ini mengindikasikan bahwa perusahaan sedang mengalami kerugian. Sedangkan ditahun 2015 perusahaan berhasil keluar dari zona kebangkrutan karena hampir semua variabel $\mathrm{X}$ mengalami peningkatan sedangkan variabel X4 memiliki nilai tetap dan berhasil meningkatkan nilai $\mathrm{Z}$ menjadi 2,18 untuk masuk dalam grey zones. Variabel yang mendominasi peningkatan adalah variabel X5 yang menggambarkan perusahaan telah secara optimal melakukan peningkatan volume penjualan.

\section{PT Merck Tbk}

Tabel 8 berikut ini menggambarkan hasil perhitungan Z-Score PT Merck Tbk untuk tahun 2013 sampai dengan 2015.

Tabel 8. Hasil Perhitungan Z-Score PT Merck Tahun 2013-2015

\begin{tabular}{|c|c|c|c|c|c|c|c|}
\hline $\begin{array}{l}\text { RA } \\
\text { TIO }\end{array}$ & 2013 & 2014 & 2015 & \multicolumn{2}{|c|}{$\begin{array}{l}\text { Dari } \\
2013 \\
\text { ke } \\
2014\end{array}$} & \multicolumn{2}{|c|}{$\begin{array}{l}\text { Dari } \\
2014 \\
\text { ke } \\
2015\end{array}$} \\
\hline $\mathrm{X} 1$ & 0,632 & 0,65 & 0,547 & $\nearrow$ & $\begin{array}{l}0, \\
01 \\
8\end{array}$ & $\searrow$ & $\begin{array}{l}0,1 \\
03\end{array}$ \\
\hline $\mathrm{X} 2$ & 0,667 & 0,704 & 0,676 & $\pi$ & $\begin{array}{l}0, \\
03 \\
7\end{array}$ & $\searrow$ & $\begin{array}{l}0,0 \\
28\end{array}$ \\
\hline X3 & 0,282 & 0,286 & 0,306 & $\pi$ & $\begin{array}{l}0, \\
00 \\
4\end{array}$ & $\lambda$ & $\begin{array}{l}0,0 \\
20\end{array}$ \\
\hline $\mathrm{X} 4$ & 0,115 & 0,134 & 0,133 & $\lambda$ & $\begin{array}{l}0, \\
01 \\
9\end{array}$ & $\searrow$ & $\begin{array}{l}0,0 \\
01\end{array}$ \\
\hline X5 & 1,156 & 1,205 & 1,533 & $\pi$ & $\begin{array}{l}0, \\
04 \\
9\end{array}$ & $\searrow$ & $\begin{array}{l}0,3 \\
28\end{array}$ \\
\hline $\begin{array}{l}\text { Z- } \\
\text { Scor } \\
\text { e } \\
\end{array}$ & 3,85 & 3,99 & 4,21 & & & & \\
\hline
\end{tabular}

\begin{tabular}{|l|l|l|l|}
$\begin{array}{l}\text { Kate } \\
\text { gori }\end{array}$ & $\begin{array}{l}\text { Safe } \\
\text { Zones }\end{array}$ & $\begin{array}{l}\text { Safe } \\
\text { Zones }\end{array}$ & $\begin{array}{l}\text { Safe } \\
\text { Zones }\end{array}$ \\
\hline
\end{tabular}

Sumber: data diolah

PT Merch selama tiga tahun berturut-turut berada dalam posisi safe zone. Pada tahun 2013 dengan nilai Z-Score yaitu 3,85 dengan peningkatan seluruh variabel pada tahun 2014 maka nilai Z-Score meningkat menjadi 3,99. Variabel X5 adalah variabel yang mengalami peningkatan yang mendominasi artinya perusahaan mengalami peningkatan penjualan dan perusahaan berhasil meningkatkan volume bisnis yang cukup dibandingkan investasi dalam total aktivanya. Peningkatan nilai ZScore juga terjadi pada tahun 2015 namun hanya variabel X3 saja yang mengalami peningkatan dan hal ini menandakan bawa perusahaan berhasil meningkatkan kinerja perusahaan untuk menghasilkan laba Rasio ini merupakan rasio yang dianggap paling berpengaruh dalam menilai kondisi keuangan perusahaan.

\section{PT Pytidam Farma Tbk}

Tabel 9 berikut ini menggambarkan hasil perhitungan Z-Score PT Pytidam Farma Tbk untuk tahun 2013 sampai dengan 2015. Hasil penelitian menunjukkan bahwa selama tiga tahun berturut-turut perusahaan mengalami posisi grey zone. Peningkatan dari tahun 2013 ke tahun 2014 diikuti peningkatan 4 variabel dan yang mendominasi peningkatan adalah variabel X5 yang membuktikan adanya peningkatan penjualan untuk menghasilkan laba lebih. Dan variabel X3 mengalami penurunan yang menandakan perusahaan mengalami penurunan kemampuan untuk menghasilkan laba dari aktiva. Penurunan pada rasio ini dapat dijadikan sebagai tanda adanya indikator kebangkrutan. 
Tabel 9. Hasil Perhitungan Z-Score PT Pyridam Farma Tahun 2013-2015

\begin{tabular}{|c|c|c|c|c|c|c|c|}
\hline $\begin{array}{l}\text { RA } \\
\text { TIO }\end{array}$ & 2013 & 2014 & 2015 & \multicolumn{2}{|c|}{$\begin{array}{l}\text { Dari } \\
2013 \\
\text { ke } \\
2014\end{array}$} & \multicolumn{2}{|c|}{$\begin{array}{l}\text { Dari } \\
2014 \\
\text { ke } \\
2015\end{array}$} \\
\hline $\mathrm{X} 1$ & 0,150 & 0,174 & 0,226 & $\lambda$ & $\begin{array}{l}0,0 \\
24 \\
\end{array}$ & $\lambda$ & $\begin{array}{l}0, \\
05 \\
2\end{array}$ \\
\hline $\mathrm{X} 2$ & 0,220 & 0,241 & 0,285 & $\lambda$ & $\begin{array}{l}0,0 \\
21\end{array}$ & $\nearrow$ & $\begin{array}{l}0, \\
04 \\
4\end{array}$ \\
\hline X3 & 0,049 & 0,030 & 0,028 & $\searrow$ & $\begin{array}{l}- \\
0,0 \\
19\end{array}$ & $\searrow$ & $\begin{array}{l}- \\
0, \\
00 \\
2\end{array}$ \\
\hline X4 & 0,659 & 0,709 & 0,911 & $\lambda$ & $\begin{array}{l}0,0 \\
50 \\
\end{array}$ & $\lambda$ & $\begin{array}{l}0, \\
20 \\
2\end{array}$ \\
\hline X5 & 1,100 & 1,288 & 1,362 & $\lambda$ & $\begin{array}{l}0,1 \\
88\end{array}$ & $\lambda$ & $\begin{array}{l}0 \\
07 \\
4\end{array}$ \\
\hline $\begin{array}{l}\text { Z- } \\
\text { Scor } \\
\mathrm{e}\end{array}$ & 2,14 & 2,36 & 2,67 & & & & \\
\hline $\begin{array}{l}\text { Kate } \\
\text { gori }\end{array}$ & $\begin{array}{l}\text { Grey } \\
\text { Zones } \\
\end{array}$ & $\begin{array}{l}\text { Grey } \\
\text { Zones }\end{array}$ & $\begin{array}{l}\text { Grey } \\
\text { Zones }\end{array}$ & & & & \\
\hline
\end{tabular}

Sumber: data diolah

Pada tahun 2015 nilai Z-Score terus meningkat menjadi 2,67 bila perusahaan bisa terus memperbaiki kinerjanya dan terus meningkatkan nilai perusahaan maka tahun-tahun yang akan datang ada kemungkinan perusahaan bisa berada dalam safe zones. Perusahaan harus meningkatkan kemampuan mengolah hasil laba terhadap aktiva agar pada tahun berikutnya dapat keluar dari grey zones.

\section{PT Taisho Pharmaceutical Indonesia}

Tabel 10 berikut ini menggambarkan hasil perhitungan Z-Score PT Taisho Pharmaceutical Tbk untuk tahun 2013 sampai dengan 2015.
Tabel 10. Hasil Perhitungan Z-Score PT Taisho Pharmaceutical Indonesia Tahun 2013-2015

\begin{tabular}{|c|c|c|c|c|c|c|c|}
\hline $\begin{array}{l}\text { RA } \\
\text { TIO }\end{array}$ & 2013 & 2014 & 2015 & \multicolumn{2}{|c|}{$\begin{array}{l}\text { Dari } \\
2013 \\
\text { ke } \\
2014\end{array}$} & \multicolumn{2}{|c|}{$\begin{array}{l}\text { Dari } \\
2014 \\
\text { ke } \\
2015\end{array}$} \\
\hline $\mathrm{X} 1$ & 0,624 & 0,627 & 0,567 & $\lambda$ & $\begin{array}{l}0,0 \\
03\end{array}$ & $\searrow$ & $\begin{array}{l}- \\
0,0 \\
6\end{array}$ \\
\hline $\mathrm{X} 2$ & 0,617 & 0,625 & 0,575 & $\lambda$ & $\begin{array}{l}0,0 \\
08\end{array}$ & $\searrow$ & $\begin{array}{l}- \\
0,0 \\
5\end{array}$ \\
\hline X3 & 0,474 & 0,489 & 0,131 & $\lambda$ & $\begin{array}{l}0,0 \\
15\end{array}$ & $\searrow$ & $\begin{array}{l}- \\
0,3 \\
58\end{array}$ \\
\hline $\mathrm{X} 4$ & 0,013 & 0,011 & 0,009 & $\searrow$ & $\begin{array}{l}- \\
0,0 \\
02\end{array}$ & $\searrow$ & $\begin{array}{l}-\overline{-} \\
0,0 \\
02\end{array}$ \\
\hline X5 & 1,012 & 1,105 & 1,109 & $\lambda$ & $\begin{array}{l}0,0 \\
93\end{array}$ & $\pi$ & $\begin{array}{l}0,0 \\
04\end{array}$ \\
\hline $\begin{array}{l}\text { Z- } \\
\text { Scor } \\
\text { e }\end{array}$ & 4,20 & 4,35 & 4,01 & & & & \\
\hline $\begin{array}{l}\text { Kate } \\
\text { gori }\end{array}$ & $\begin{array}{l}\text { Safe } \\
\text { Zones }\end{array}$ & $\begin{array}{l}\text { Safe } \\
\text { Zones }\end{array}$ & $\begin{array}{l}\text { Safe } \\
\text { Zones }\end{array}$ & & & & \\
\hline
\end{tabular}

Sumber: data diolah

PT Taisho Pharmaceutical Indonesia berhasil menduduku safe zones selam tiga tahun berturut-turut dengan nilai $\mathrm{Z}$ yaitu 4,20 ditahun 2013, 4,35 ditahun 2014 dan 4,01 ditahun 2015. Terjadi peningkatan dari tahun 2013 ke tahun 2014 yang diikuti dengan peningkatan nilai variabel X1, X2, X3 dan X5, dengan variabel X5 yang mendominasi peningkatan yang menandai penjualan pada tahun tersebut meningkat. Namun ada penurunan ditahun 2015 dengan nilai Z-Score yaitu 4,01. Pada tahun 2015 keadaan perusahaan berbalik dengan penurunan variabel $\mathrm{X} 1, \mathrm{X} 2, \mathrm{X} 3, \mathrm{X} 4$ dan variabel yang mendominasi penurunan adalah variabel X3 yang menggambarkan kemampuan perusahaan dalam mengolah laba pada aktiva.

\section{PT Tempo San Pacific}

Tabel 11 berikut ini menggambarkan hasil perhitungan Z-Score PT Tempo San Pasific Tbk untuk tahun 2013 sampai dengan 2015. 
Tabel 11. Hasil Perhitungan Z-Score PT Tempo Scan Pacific Tahun 20132015

\begin{tabular}{|c|c|c|c|c|c|c|c|}
\hline $\begin{array}{l}\text { RA } \\
\text { TIO }\end{array}$ & 2013 & 2014 & 2015 & \multicolumn{2}{|c|}{$\begin{array}{l}\text { Dari } \\
2013 \\
\text { ke } \\
2014\end{array}$} & \multicolumn{2}{|c|}{$\begin{array}{l}\text { Dari } \\
2014 \\
\text { ke } \\
2015\end{array}$} \\
\hline $\mathrm{X} 1$ & 0,488 & 0,442 & 0,482 & $\searrow$ & $\begin{array}{l}0, \\
0 \\
4 \\
6 \\
\end{array}$ & $\nearrow$ & $\begin{array}{l}0, \\
0 \\
4\end{array}$ \\
\hline $\mathrm{X} 2$ & 0,577 & 0,596 & 0,667 & $\lambda$ & $\begin{array}{l}0, \\
0 \\
1 \\
9\end{array}$ & $\nearrow$ & $\begin{array}{l}0, \\
0 \\
7 \\
1\end{array}$ \\
\hline X3 & 0,153 & 0,132 & 0,131 & $\searrow$ & $\begin{array}{l}0, \\
0 \\
2 \\
1 \\
\end{array}$ & $\searrow$ & $\begin{array}{l}0, \\
0 \\
0 \\
1\end{array}$ \\
\hline X4 & 0,142 & 0,147 & 0,116 & $\lambda$ & $\begin{array}{l}0, \\
0 \\
0 \\
5\end{array}$ & $\searrow$ & $\begin{array}{l}0, \\
0 \\
3 \\
1\end{array}$ \\
\hline X5 & 1,265 & 1,339 & 1,510 & $\pi$ & $\begin{array}{l}0, \\
0 \\
7 \\
4\end{array}$ & $\nearrow$ & $\begin{array}{l}0, \\
1 \\
7 \\
1\end{array}$ \\
\hline $\begin{array}{l}\text { Z- } \\
\text { Scor } \\
\mathrm{e} \\
\text { Kate } \\
\text { gori } \\
\end{array}$ & $\begin{array}{l}3,25 \\
\text { Safe } \\
\text { Zones }\end{array}$ & $\begin{array}{l}3,23 \\
\text { Safe } \\
\text { Zones }\end{array}$ & $\begin{array}{l}3,52 \\
\text { Safe } \\
\text { Zones }\end{array}$ & & & & \\
\hline
\end{tabular}

Sumber: data diolah

Selama tiga tahun berturut-turut perusahaan mengalami posisi Safe Zones dengan nilai $Z$ ditahun 2013 yaitu 3,25, tahun 2014 yaitu 3,23 dan ditahun 2015 yaitu 3,52. Dapat dilihat penurunan dari tahun 2013 ke tahun 2014 namun ada peningkatan pada tahun 2015. Variabel yang mempengaruhi penurunan tahun 2014 adalah X1 dan X3 yang menandakan perusahaan kurang efisien dalam menghasilkan modal kerja bersih dari keseluruhan aktiva serta kurang efisien dalam mengelola laba sebelum pembayaran pada dan bunga. Sedangkan Variabel yang meningkat adalah variabel $\mathrm{X} 2$, X4 dan X5. Dengan variabel X5, adanya peningkatan jumlah permintaan produk yang berpengaruh pada peningkatan penjualan. Untuk tahun 2015 variabel X yang mempengaruhi peningkatan yaitu variabel X1,X2 dan X5.Dengan variabel dominan yang masih sama dari tahun sebelumnya yaitu X5.

\section{PEMBAHASAN}

Hasil analisis terhadap 10 perusahaan farmasi yang diteliti menunjukkan bahwa sebagian perusahaan dalam kondisi grey, artinya perusahaan perlu mengantisipasi adanya potensi kebangkrutan dengan meningkatkan kinerja keuangannya agar perusahaan berada dalam kondisi yang aman (safe). Tidak sedikit pula dari sampel penelitian menunjukkan bahwa perusahaan dalam kondisi safe sehingga perusahaan harus berusaha tetap mempertahankan keadaannya agar tidak masuk dalam grey zones ataupun distress zones.

Dari hasil penelitian hanya ada satu perusahaan yang berada dalam kondisi Distres Zones, perusahaan yang mengalami financial distress ini adalah PT Merck Sharp Dohme Tbk yang selama dua tahun berada dalam posisis distres namun pada tahun ketiga berhasil meningkatkan posisi perusahaannya menjadi grey zones. Artinya selama dua tahun mengalami kesulitan keuangan, perusahaan terus memaksimalkan kinerjanya sehingga pada tahun ketiga berhasil keluar dari zona kebangkrutan. Namun perusahaan masih harus terus berusaha lebih agar perusahaan benar-benar dinyatakan aman (safe) atau sehat.

Hasil penelitian juga mengindikasikan terdapat lima perusahaan yang selama tiga tahun berturut-turut berhasil mempertahankan nilai perusahaannya untuk tetap berada dalam kondisi sehat (safe zones). Kelima perusahaan tersebut adalah PT Industri Jamu dan Farmasi Sido Muncul Tbk, PT Kalbe Farma Tbk, PT Merck Tbk, PT Taisho Pharmaceutical Indonesia Tbk dan PT Tempo Scan Pacific 
Tbk. Dari kelima perusahaan yang berada dalam kondisi sehat selama tiga tahun ini, perusahaan dengan nilai Z-Score tertinggi adalah PT Industri Jamu dan Farmasi Sido Muncul Tbk. Perusahaan ini bertahan secara konsisten selama tiga tahun berturutturut tetap memiliki nilai $\mathrm{Z}$ tertinggi dibandingkan perusahaan lainnya.

Variabel yang paling banyak mempengaruhi terjadinya penurunan nilai Z-Score adalah variabel X1 dan X4 dimana kemampuan likuiditas dan solvabilitas perusahaan banyak yang menurun. Perusahaan harus lebih meningkatkan modal kerja yang dimiliki serta modal saham untuk menanggung beban hutang perusahaan.

Sepuluh perusahaan farmasi yang diteliti merupakan perusahaan dalam ukuran besar karena memiliki total asset lebih dari 100 milyar rupiah, namun jumlah asset yang banyak tidak menjamin perusahaan dalam kondisi aman (safe). Lamanya perusahaan berdiri dan pengalaman perusahaan selama bertahun-tahun yang mampu mejadikan perusahaan lebih berkompeten karena memiliki pengalaman yang lebih banyak dalam menangani masalah perusahaan.Perusahaan dengan umur yang lama lebih baik dalam mengelola kinerja keuangannya sehingga nilai Z-Score perusahaan cenderung lebih tinggi jika dibandingkan dengan perusahaan yang baru berdiri

\section{SIMPULAN DAN SARAN}

Penelitian ini dilakukan untuk memprediksi mengetahui hasil penilaian financial distress pada perusahaan farmasi yang sudah melakukan Go Public dengan menggunakan metode AltmanZ-Score. Setelah dilakukan perhitungan nilai $Z$ Score yang dihasilkan oleh 10 perusahaan farmasi yang terdapat pada sampel penelitian, terdapat perusahaan yang mengalami peningkatan yang konsisten dari tahun 2013-2015, ada yang mengalami penurunan yang konsisten dari tahun 20132015 , dan ada juga yang tetap dari tahun 2013-2015.

Adapun penelitian memiliki keterbatasan terkait periode penelitian untuk sampel perusahaan yaitu tiga periode yaitu 20132015 serta sampel dalam penelitian ini hanya mengambil perusahaan farmasi yang terdaftar di Bursa Efek Indonesia (BEI). Penelitian yang akan datang disarankan untuk menambah periode penelitian dan dikembangkan pada perusahaan farmasi baik yang go public maupun yang belum agar dapat menggambarkan kondisi industri farmasi yang ada di Indonesia. Penelitian selanjutnya dapat pula dikembangkan dengan menggunakan metode lain sebagai pembanding hasil prediksi kebangkrutan.

\section{DAFTAR PUSTAKA}

Arini, Sopiyah dan Triyonowati. (2013). Analisis Altman Z-Score Untuk Memprediksi Kebangkrutan pada Perusahaan Farmasi di Indonesia. Surabaya: Sekolah Tinggi Ilmu Ekonomi Indonesia.

Bursa Efek Indonesia. www.idx.co.id

BPS. (2017). Proyeksi Penduduk menurut Provinsi, 2010-2035. Badan Pusat Statistik.

https://www.bps.go.id/linkTabelSta tis/view/id/1274. Diunduh pada 9 Maret 2017

Dewi, Nur Fajrina. (2014). Model Prediksi Financial Distress Untuk Mendeteksi Kebangkrutan Pada Industri Perbankan. http://www.academia.edu/1129849 9/BAB_II_Model_Prediksi_Financ ial_Distress_Untuk_Memprediksi_ Potensi_Kebangkrutan_Pada_Indus tri_Perbankan. Diunduh pada 27 Juli 2016. 
Ferbianasari, Hilda Nia. (2012). Analisis Penilaian Financial Distress Menggunakan Model Altman ZScore pada Perusahaan Kosmetik yang Tercatat di Bursa Efek Indonesia. Surabaya: Universitas Negeri Surabaya.

Irfan, Mochamad dan Tri Yuniati. (2014). Analisis Financial Distress dengan Pendekatan Altman Z-Score untuk Memprediksi Kebangkrutan Perusahaan Telekomunikasi. Surabaya: Sekolah Tinggi Ilmu Ekonomi Indonesia.

Investor Daily. (2015). BPJS Dongkrak Pasar Farmasi Jadi Rp 69 Triliun. http://kemenperin.go.id/artikel/10 433/BPJS-Dongkrak-PasarFarmasi-Jadi-Rp-69-T. Diunduh pada 19 Juni 2016.

Marcelina, Pandu Dian. (2011). Analisis Arus Kas dan Laba dalam Memprediksi Finansial Distress Perusahaan. Jember: Universitas Jember.

Nasution, Andini Putri. (2015). Pengaruh Likuiditas dan Profitabilitas Terhadap Finansial Distress pada Perusahaan Farmasi yang Terdaftar di Bursa Efek Indonesia Periode2010-2014. Palembang: Politeknik Negeri Sriwijaya.

Nugroho, Mokhamad Iqbal Dwi dan Wisnu Mawardi. (2012). Analisis Prediksi Financial

Distress dengan Menggunakan

Model Altman Z-Score Modifikasi 1995 Studi Kasus
Pada Perusahaan Manufaktur Yang Go Public di Indonesia Tahun 2008 sampai dengan Tahun 2010. Semarang: Universitas Diponegoro.

Pryambodo, Bambang. (2014). Menjelang AEC 2015, Sudah Siapkah Industri Farmasi Kita.

https://priyambodo1971.wordpress. com/2014/03/21/menjelang-aec2015-sudah-siapkah-industrifarmasi-kita/. Diunduh pada 22 Juni 2016.

IAI. (2012). Pernyataan Standar Akuntansi Keuangan. Salemba. Jakarta.

Riadi, Muchlisin.(2015). Definisi Metode Altman Z-Score. http://www.kajian pustaka.com/2013/03/metodealtman-z-score.html?m=1. Diunduh pada 27 Juli 2016.

Sekaran, Uma. (2006). Metodologi Penelitian untuk Bisnis, Buku 1, Edisi 4. Salemba. Jakarta.

Yuliastari, Etta Citrawati dan Made Gede Wirakusuma. (2014). Analisis Financial Distress dengan Metode Z-Score Altman, Springate, Zmijewski. Bali: Universitas Udayana.

Zakiah, Farah. (2011). Analisis Rasio Keuangan dalam Memprediksi Kondisi Financial

Distress Perusahaan. http://farahzhaqia.blogspot.cp.id/20 11/03/analisisrasiokeuangandalam.

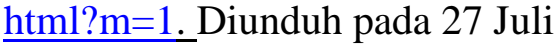
2016. 